\title{
Perancangan Aplikasi Panduan Belajar Pengenalan Ortodonsia Menggunakan Animasi $3 \mathrm{D}$
}

\author{
Jinifer Rori $^{(1)}$, Steven Sentinuwo ${ }^{(2)}$, Stanley Karouw ${ }^{(3)}$ \\ Teknik Informatika, Universitas Sam Ratulangi, Manado, Indonesia. \\ Email: jinifer20@gmail.com, steven@unsrat.ac.id, stanley.karouw@unsrat.ac.id
}

\begin{abstract}
Abstrak --- Perancangan aplikasi panduan belajar pengenalan ortodonsia menggunakan animasi 3D merupakan e-learning, yang dibuat untuk menjelaskan alat bantu ajar mata kuliah ortodonsia dengan menggunakan teknologi animasi 3D. Mengubah materi dan ilustrasi berupa animasi 3D yang menarik sehingga mahasiswa lebih mudah mengerti. Data yang di jadikan sebagai kebutuhan pembuatan aplikasi didapatkan dari wawancara kepada dosen pengampu mata kuliah ortodonsia di fakultas kedokteran gigi UNSRAT. Metode pengembangan aplikasi yang digunakan adalah Rapid Aplication Development. Dengan teknologi yang digunakan, tools pembuatan 3 Dimensi blender dan Blender Game Engine untuk membuat aplikasi interaktif.
\end{abstract}

Kata Kunci -- Ortodonsia, RAD, e-learning

\section{PENDAHULUAN}

Pemanfaatan media pembelajaran berbasis komputer merupakan terobosan baru dalam proses pembelajaran dan mereka yang berniat menjadi dokter gigi harus dapat belajar mengenali ilmu yang bertujuan memperbaiki atau membetulkan letak gigi yang tidak teratur dan tidak rata (Ortodonsia). Namun pengenalan berbagai alat orto kepada mahasiswa tidaklah mudah. Hal ini sering dikarenakan metode pembelajaran yang tidak efektif. Seperti cara penyampaian melalui buku yang di dalamnya hanyalah berupa text dan gambar-gambar yang hanya berupa 2 dimensi (2D).[1]

Oleh karena itu mahasiswa kedokteran gigi membutuhkan inovasi yang baru dalam media pembelajaran yang dapat mereka gunakan. Saat ini komputer sudah menjadi kebutuhan yang dapat memungkinkan untuk bisa memudahkan manusia belajar maupun bekerja. Seperti dengan pengunaan aplikasi e-learning, website, video tutorial dll.

\section{LANDASAN TEORI}

\section{A. Ortodontik}

Menurut Buku Ajar Ortodonsia I, istilah ortodontik berasal dari kata Ortodonsia. Ortodonsia (Orthodontia, Bld., Orthodontic, Ingg.) berasal dari bahasa Yunani (Greek) yaitu orthos dan dons yang berarti orthos (baik, betul) dan dons (gigi). Jadi ortodonsia dapat diterjemahkan sebagai ilmu pengetahuan yang bertujuan memperbaiki atau membetulkan letak gigi yang tidak teratur atau tidak rata.

Keadaan gigi yang tidak teratur disebabkan oleh malposisi gigi, yaitu kesalahan posisi gigi pada masing - masing rahang. Malposisi gigi akan menyebabkan malrelasi, yaitu kesalahan hubungan antara gigi - gigi pada rahang yang berbeda. Lebih lanjut lagi keadaan demikian menimbulkan maloklusi, yaitu penyimpangan terhadap oklusi normal. Maloklusi dapat terjadi karena adanya kelainan gigi, tulang rahang, kombinasi gigi dan rahang maupun karena otot otot penguyahan.[1]

\section{B. Perancangan Aplikasi}

Perancangan Aplikasi yaitu proses merancang piranti lunak sebelum melakukan pengkodean (coding). Model adalah deskripsi dari suatu permasalahan atau topic dari aplikasi yang akan dibuat. Dengan menggunakan model ini akan membantu perancangan dalam memahami lingkup permaslahan yang akan dipecahkan. Model itu sendiri adalah visualisasi dari aplikasi yang akan dibangun. Model piranti lunak dapat dianalogikan seperti cetak biru pada suatu perancangan.[2]

\section{3 Dimensi}

3D adalah dimensi yang memiliki ruang. Jika kita merujuk kepada "objek 3D", artinya objek tersebut memiliki ruang volume. Objek 3D juga memiliki lokasi pada koordinat $\mathrm{X}, \mathrm{Y}$ dan Z. Jika pada bidang 2 dimensi anda hanya dapat menggerakkan objek tersebut ke samping.[2]

\section{Blender}

Blender merupakan software pengolah 3 dimensi (3D) untuk membuat animasi 3D, yang bisa dijalankan di windows, macintosh dan linux. Blender juga sama seperti software 3D pada umumnya seperti 3DS Max, maya dan lightwave, tetapi juga mempunyai perbedaan yang cukup mendasar seperti projek kerja di blender bisa dikerjakan dihampir semua software 3D komersial lainnya, tampilannya yang bisa diatur sesuka hati, mempunyai simulasi physics yang baik dan menggunakan uv yang lebih mudah. Blender juga dapat membuat game karena memilik Game Engine.[3]

\section{E. Animasi}

Animasi dalam bahasa Indonesia berasal dari kata "Animation". Animation berasal dari bahasa Yunani, Anima, yang berarti napas dan napas identik dengan "hidup" hingga animasi secara sederhana adalah "memberi hidup pada suatu yang tidak hidup sebelumnya”.

Ada beberapa teori umum dari definisi animation menurut berbagai versi yang dikeluarkan oleh banyak pengarang, yaitu menggerakkan benda mati seolah-olah hidup, visi gerak yang diterapkan pada benda mati, dan tampilan yang cepat dari urutan gambar-gambar 2D ataupun 3D atau model dalam posisi tertentu, untuk menciptakan ilusi gerak.[1]

\section{F. Peran Animasi Dalam Pembelajaran}


Studi meta-analisis oleh Ke, Lin, Ching, Dwyer (2006) pada animasi pembelajaran, yang membandingkan hasil-hasil penelitian dalam penggunaan animasi untuk pembelajaran, menunjukkan bahwa rata-rata, kelompok yang menggunakan animasi mengalami peningkatan pembelajaran multi-level sebesar $62 \%$, sementara kelompok yang menggunakan ilustrasi statis mengalami peningkatan sebesar 50\% saja.

Penelitian yang sama, oleh Ke, Lin, Ching, Dwyer (2006), juga memperlihatkan bahwa efektifitas animasi bervariasi untuk setiap level pembelajaran. Jika dibandingkan dengan ilustrasi statis, animasi jauh lebih dapat meningkatkan ketekunan dalam belajar. $80 \%$ siswa yang menerima pembelajaran dengan animasi menunjukkan kesungguhan dalam belajar lebih besar jika dibandingkan dengan mereka yang menerimanya dengan gambar statis. Selain itu, dibandingkan ilustrasi statis, animasi lebih sukses dalam membantu siswa dalam mengembangkat pengetahuan yang sifatnya faktual dan akurasi dalam tes aplikasi atau kinerja. Rata-rata $64 \%$ siswa di kelompok animasi mendapatkan nilai yang lebih tinggi dalam ujian yang berhubungan dengan pengetahuan faktual dan aplikasi dibandingkan siswa di kelompok yang mengunakan ilustrasi statis.[7]

\section{G. Rapid Aplication Development (RAD)}

RAD merupakan model proses perangkat lunak yang menekankan pada daur pengembangan hidup yang singkat. RAD merupakan versi adaptasi cepat dari model waterfall, dengan menggunakan pendekatan konstruksi komponen. [4.5]

Pada Metodologi RAD teradapat tahapan pengembangan apliaksi dari tiap-tiap fase sebagai berikut:

1. Requirements Planning (Analisis Persyaratan)

Dalam fase ini, pengguna dan penganalisis bertemu untuk mengidentifikasikan tujuan-tujuan aplikasi atau sistem serta untuk mengidentifikasikan syratsyarat informasi yang ditimbulkan dari tujuantujuan tersebut. Orientasi dalam fase ini adalah menyelesaikan masalah-masalah perusahaan. Meskipun teknologi informasi dan sistem bisa mengarahkan sebagian dari sistem yang diajukan, fokusnya akan selalu tetap pada upaya pencapaian tujuan-tujuan perusahaan.

2. RAD Design Workshop (Pemodelan)

Mengidentifikasi solusi alternative dan memilih solusi yang terbaik. Kemudian membuat desain proses bisnis dan desain pemrograman untuk datadata yang telah didapatkan dan dimodelkan dalam arsitektur sistem informasi. Tools yang digunakan dalam pemodelan sistem biasanya menggunakan Unified Modeling Language (UML).

3. Implementation (Implementasi)

Setelah Design Workshop dilakukan, selanjutnya sistem di- implementasikan (coding) kedalam bentuk yang dimengerti oleh mesin yang diwujudkan dalam bentuk program atau unit program. Tahap implementasi sistem merupakan tahap meletakkan sistem supaya siap untuk dioperasikan.
III. METODE PENELITIAN

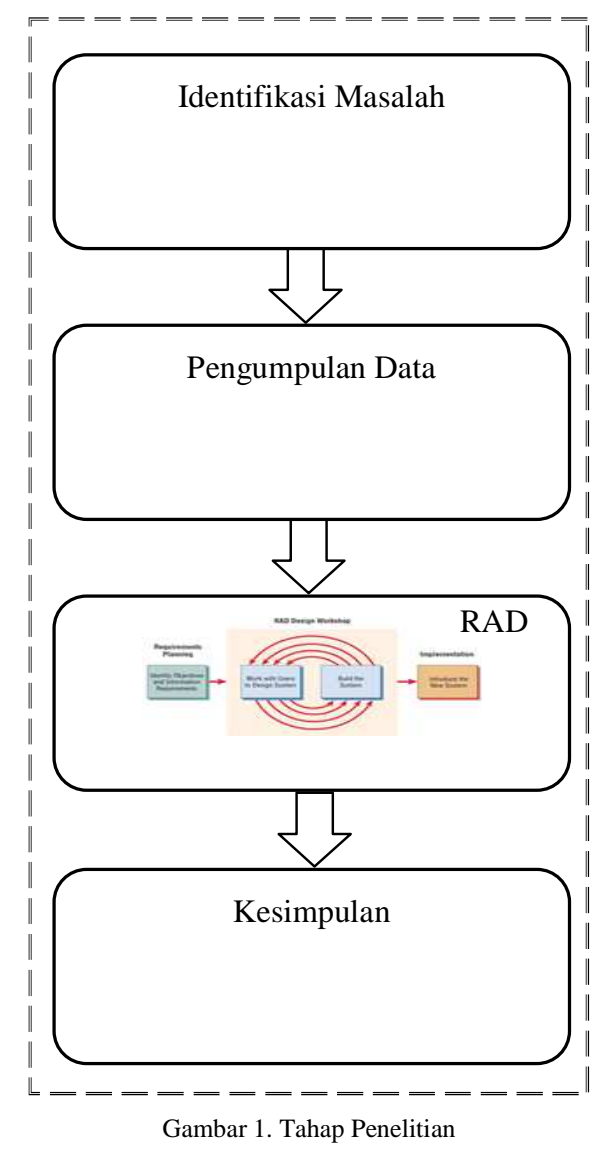

1. Identifikasi Masalah

1.1 Pembelajaran yang masih belum efektif dengan menggunakan teks dan gambar 2 dimensi

1.2 Pemanfaatan teknologi sebagai media pembelajaran masih kurang.

2. Pengumpulan Data

Ada dua tahap penulis mengumpulkan data

1. Wawancara

Wawancara dilakukan pada pengajar yang memberikan mata kuliah ortodonsia. Wawancara dilakukan untuk mendapatkan informasi informasi ortodonsia serta alat - alat yang dikenalkan pada mahasiswa yang akan dijadikan kebutuhan dari pengembangan aplikasi yang akan di rancang.

2. Study Literatur

Materi Kuliah Ortodonsia yang digunakan fakultas kedokteran gigi Unsrat.

3. Perancangan Sistem (RAD)

Perancangan sistem akan membahas mengenai cara kerja aplikasi yang terdiri dari:

a. Use Case Diagram

Use case diagram menggambarkan fungsionalitas yang diharapkan dari sebuah sistem. Sebuah use case merepresentasikan sebuah interaksi antara aktor dengan sistem. 


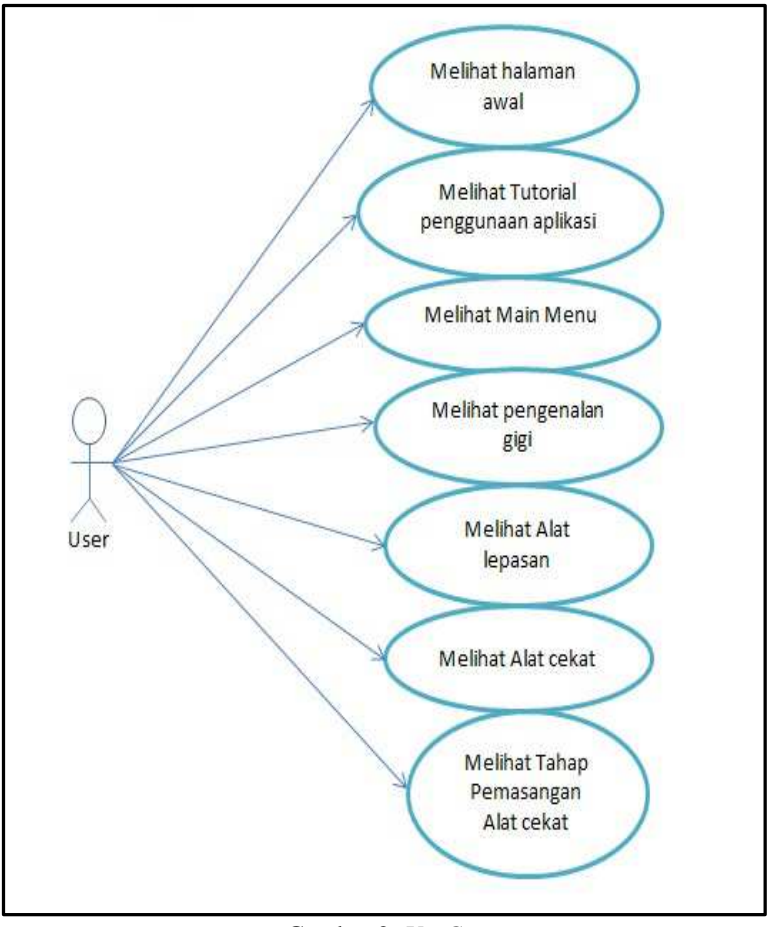

Gambar 2. UseCase

\section{b. Storyboard}

Storyboard berperan sebagai gambaran dasar dari sebuah aplikasi yang akan kita bangun berikutnya, ini merupakan cetak biru dari rangkain kegiatan atau kejadian dari setiap scene atau interface. Diharapkan dari pembuatan storyboard ini bisa dibaca dengan mudah oleh pembuat dan orang - orang yang terlibat dalam pembuatan aplikasi ortodontik.

\section{TABEL 1. STORYBOARD}

\begin{tabular}{|c|c|c|c|}
\hline Interface & Visual & Deskripsi & Durasi \\
\hline 1 & 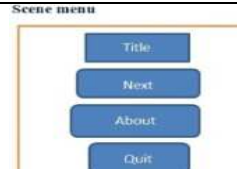 & $\begin{array}{c}\text { Tittle judula aplikasi } \\
\text { Next, tombol ke scene main } \\
\text { menu } \\
\text { Tutorial, untuk kehalamann cara } \\
\text { menggunakakan aplikasi } \\
\text { Quit, tombol kelluar dari aplikasi }\end{array}$ & 15 detik \\
\hline 2 & 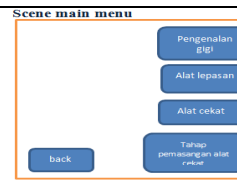 & $\begin{array}{l}\text { Main menu terdapat berabagai } \\
\text { pilithan ortodontik }\end{array}$ & 2 detik \\
\hline 3 & 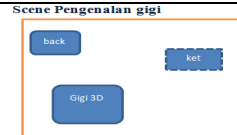 & $\begin{array}{c}\text { Disini user dapa melihat objek } \\
\text { gigi 3dimensi yang dapat di } \\
\text { gerakkan sesuai kebutuhan dan } \\
\text { mengetahui keterangan/nama } \\
\text { dari setiap gigi }\end{array}$ & 4 detik \\
\hline 4 & $\begin{array}{l}\text { Scene Alat Lepasan } \\
\text { back } \\
\end{array}$ & $\begin{array}{l}\text { user dapat memilih mana yang } \\
\text { akan dilahat }\end{array}$ & 7 detik \\
\hline
\end{tabular}

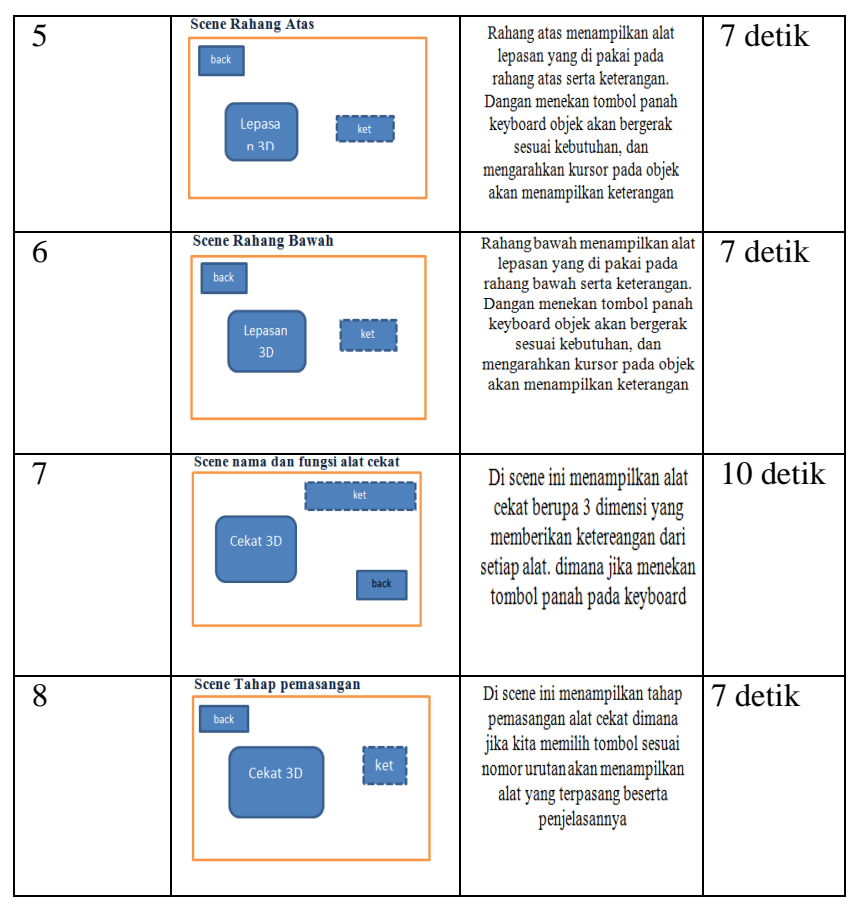

\section{IV.HASIL DAN PEMBAHASAN}

4.1 Pembuatan Objek 3D

a. Modeling Objek

Modeling dibuat dengan memanfaatkan beberapa model yang terdapat dalam menu standard primitive pada blender 3 dimensi. Seprti: Cube, Plane, Circle dan Cylinder. Pada pembuatan model ini memakai objek dasar circle dan di extrude untuk membentuk objek

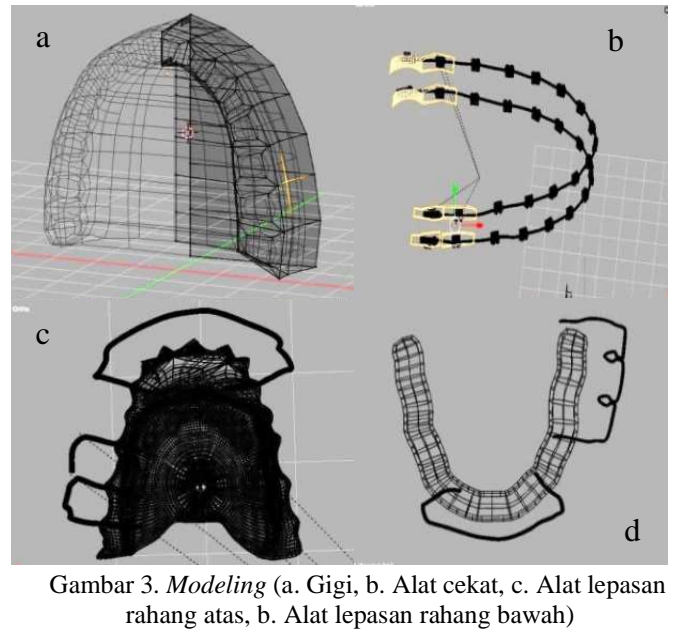

Gambar a, modeling gigi, dengan menggunakan objek awal circle yang bagian bawah dari circle di hilangkan lalu di extrude membentuk gigi. Gambar b, Modeling Alat Cekat, dengan menggunakan objek awal circle lalu di extrude membentuk alat cekat. Gambar c, modeling alat lepasan rahang atas menggunakan objek awal circle lalu di extrude membentuk alat lepasan rahang atas. Gambar d, modeling alat lepasan untuk rahang bawah dengan menggunakan objek awal circle di extrude menjadi alat lepasan rahang bawah. 
b. Pemberian Material

Material yaitu pemberian warna pada model objek 3 dimensi yang telah dibuat sebelumnya. Langkah-langkah pemberian material pada objek ialah dengan cara memilih objek lalu masuk kedalam propertis panel dan memilih material.

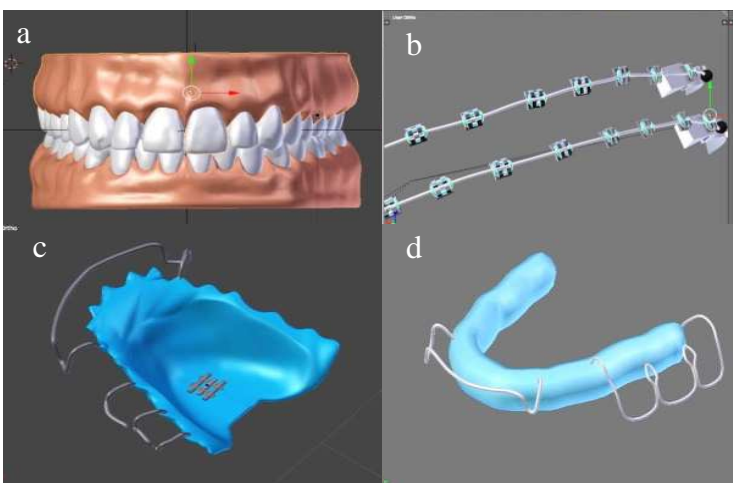

Gambar 4. Material (a. Gigi, b. Alat cekat, c. Alat lepasan rahang atas, b. Alat lepasan rahang bawah)

Gambar a, objek terbagi 2 yang di beri material pertama objek gingiva/gusi dengan warna orange kemerahan, sedangkan dons/gigi warna putih. Gambar $\mathrm{b}$, untuk objek wire yang melengkung diberi warana abu-abu, objek bracket diberi warna abu-abu tua dan elastic tie/karet diberi warna biru mudah. Gambar c, alat lepasan rahang bawah untuk plat dasar diberi material berwarna biru muda dan untuk kawat di beri warana abu-abu tua. Gambar d, alat lepasan untuk rahang bawah, objek plat dasar diberi warna biru dan kawat warna abu-abu tua.

\subsection{Hasil perancangan}

Hasil dari proses perancangan dan pengembangan aplikasi Ortodontik $3 D$ telah sesuai dengan hasil analisa dan pemodelan yang dilakukan. Berikut adalah tampilan setiap interface Pada Aplikasi

1. Scene Menu

Menampilkan tombol Next, Help, Quit, dimana jika kita mengklik tombol next sistem akan menampilkan halaman main menu yang tersidia pilihan alat, mengklik tombol Help menampilkan cara mengoprasikan aplikasi, mengklik About menampilkan penjelasan tentang aplikasi, mengklik tombol Quit untuk keluar dari aplikasi.

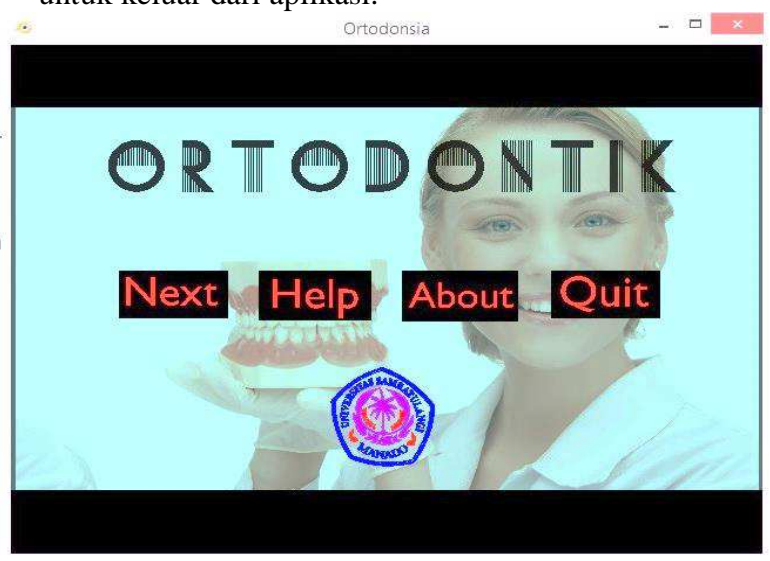

Gambar 5. Scene Menu

\section{Scene Pengenalan gigi}

Scene Pengenalan gigi Menampilkan objek gigi, dengan kita menempatkan kursor pada object gigi sistem akan menampilkan keterangan mengenai gigi tertentu. Contohnya jika kursor diarahkan pada gigi dens premolaris 2 gigi yang sorot akan berubah warna menandakan gigi itu telah terpilih dan sistem akan menampilkan penjelasan seperti benih mulai terbentuk di bulan keberapa, erupsi atau peertumbuhannya selama berapa tahun dan gigi itu akan tumbuh sempurana di tahun ke berapa.

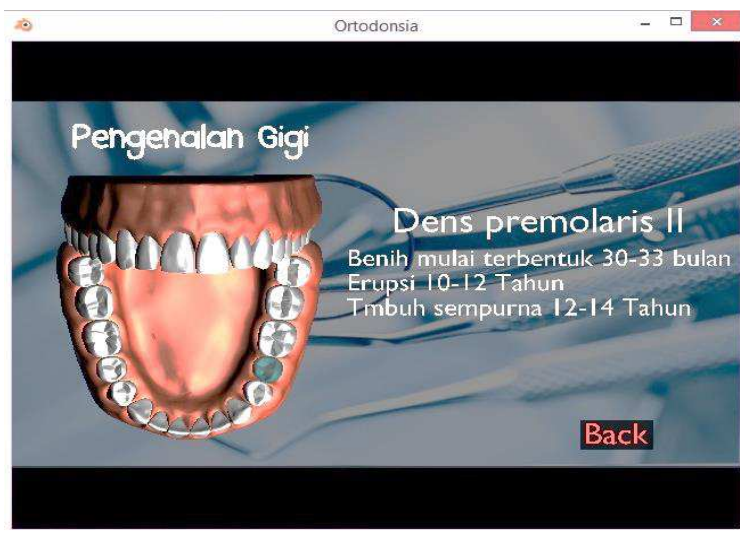

Gambar 6. Scene Pengenalan gigi

3. Scene Alat Cekat

Halaman Pengenalan alat cekat menampilkan setiap alat cekat yang digunakan seperti: bracket, wire, elastic tie, mollar band dan buccal tube, dimana setiap alat - alat tersebut memilik fungsinya masing - masing, bisa terlihat jika kursor di arahkan pada setiap objek yang ada. Contohnya jika kita menempatkan kursor pada objek bracket, sistem akan menampilkan fungsi dari alat bracket.

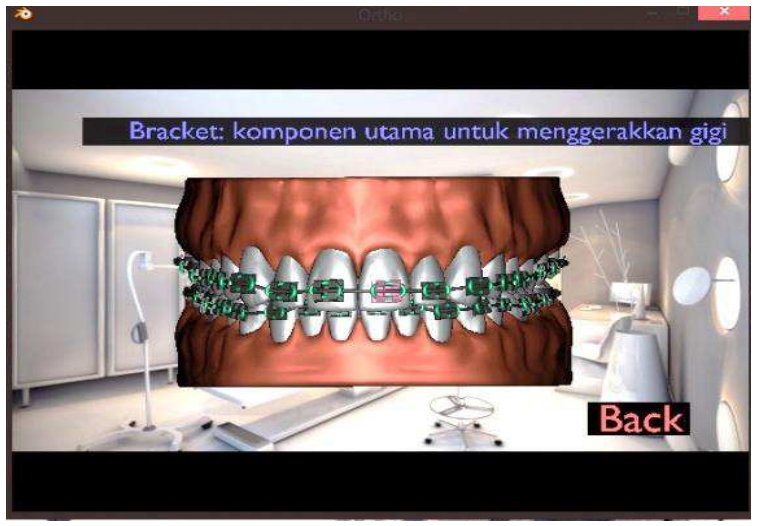

Gambar 7. Scene Alat Cekat

\section{V.PENUTUP}

\section{A. Kesimpulan}

Kesimpulan yang di dapat:

1. Aplikasi ini dibuat sebagai satu alat bantu media pembelajaran mahasiswa kedokteran gigi yang mendapatkan materi ortodonsia, yang dulunya menggunakan media buku yang 
alat-alat diperkanalkan dengan bentuk 2 dimensi akan tetapi sekarang menggunakan teknologi serta dengan adanya aplikasi ini pengguna dapat memahami materi secara efektif.

2. Menduplikasi dari garis lengkung utama menjadi beberapa garis yang lain untuk menjadikan suatu bentuk objek 3D.

B. Saran

Saran Untuk Kedepan:

1. Karena aplikasi ini hanya berbasis desktop sebaiknya bisa juga di buat dengan berbagai platform.

2. Dalam matakuliah ortodonsia masih banyak alat yang belum termuat dalam aplikasi ini.

\section{UCAPAN TERIMA KASIH}

Penulis menyampaikan terimakasih kepada, Drg. Anindita selaku Dosen fakultas Kedokteran gigi UNSRAT yang telah memberikan izin dan keluasan waktu untuk melakukan penelitian.

\section{DAFTAR PUSTAKA}

[1] Sulandjari H. 2008. Buku Ajar Ortodonsia I KGO I. Fakultas Kedokteran Gigi Universitas Gadjah Mada. Yogyakarta

[2] Febri, Ahmaddul, Asrul. 2014. Rancang Bangun Animasi 3 Dimensi Sebagai Media Pembelajaran Pada Mata Pelajaran Menginstalisasi PC. Universitas Universitas Negeri Padang.

[3] James Chronister. Blender Basics Classroom Tutorial Book. Edisi 4

[4] Karouw, Stanley., 2013, Analisa dan Perancangan Sistem Informasi Perencanaan dan Evaluasi Pembangunan Daerah (RAKOREV) Di BAPPEDA Kota Manado. Konfrensi Nasional Sistem Informasi 2013, STIMIK Bumigora Mataram 14-16 Februari 2013.

[5] Roger S.Pressman, 2012. Rekayasa Perangkat Lunak - Pendekatan Praktisi Edisi 7- Buku 1. Yogyakarta: Andi.

[6] Wayan Ardhana. 2003. Materi Kuliah Ortodonsoa 1 Alat Ortodontik Lepasan. Fakultas Kedokteran Gigi Universitas Gajah Mada. Yogyakarta.

[7] Dina Utami. 2011. Animasi Dalam Pembelajaran. Majalah Ilmiah Pembelajaran

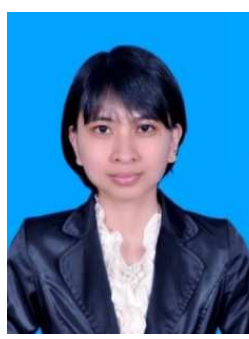

Sekilas dari penulis dengan nama lengkap Jinifer Tatiana Isye Rori, lahir pada tanggal 20 Juni 1992 di Manado, Provinsi Sulawesi Utara. Anak ke-2 dari 2 bersaudara. Dengan pendidikan pertama di Taman Kanak-Kanak Gmim Betlehem Koka, kemudian melanjutkan ke SD Gmim Koka, melanjutkan ke SMP Negeri 7 Manado, dan pada tahun 2007 melanjutkan ke SMA N 7 Manado. Setelah lulus sekolah tingkat atas pada tahun 2010 penulis melanjutkan ke Perguruan Tinggi tepatnya di Universitas Sam Ratulangi Manado, Fakultas Teknik, Jurusan Elektro, Program Studi Teknik Informatika. Penulis membuat skripsi untuk memenuhi syarat sarjana (S1) dengan judul Aplikasi panduan belajar pengenalan ortodonsia menggunakan animasi $3 D$ yang di bimbing oleh dua dosen Teknik Informatika yaitu Dr.Eng Steven Sentinuwo, ST., MTI dan Stanley D.S. Karouw, ST, MTI sehingga pada tanggal 14 April 2016 penulis resmi lulus di Teknik Informatika Universitas Sam Ratulangi Manado. 